\title{
AtROP1 negatively regulates potato resistance to Phytophthora infestans via NADPH oxidase- mediated accumulation of $\mathrm{H}_{2} \mathrm{O}_{2}$
}

\author{
Zhiwei Zhang ${ }^{1}$, Fan Yang ${ }^{1}$, Ren Na' ${ }^{1}$ Xiaoluo Zhang ${ }^{1}$, Shuqing Yang ${ }^{1}$, Jing Gao', Mingshou Fan ${ }^{1}$, Yan Zhao ${ }^{2}$ \\ and Jun Zhao ${ }^{1 *}$
}

\begin{abstract}
Background: Small GTPases are monomeric guanine nucleotide-binding proteins. In plants, ROPs regulate plant cell polarity, plant cell differentiation and development as well as biotic and abiotic stress signaling pathways.

Results: We report the subcellular localization of the AtRop1 protein at the plasma membrane in tobacco epidermal cells using GFP fusions. Additionally, transient and stable expression of a dominant negative form (DN) of the Arabidopsis AtRop1 in potato led to $\mathrm{H}_{2} \mathrm{O}_{2}$ accumulation associated with the reduced development of Phytophthora infestans Montagne de Bary and smaller lesions on infected potato leaves. The expression of the Strboh-D gene, a NADPH oxidase homologue in potato, was analyzed by RT-PCR. Expression of this gene was maintained in DN-AtRop1 transgenic plants after infection with P. infestans. In transgenic potato lines, the transcript levels of salicylic acid (SA) and jasmonic acid (JA) marker genes (Nprl and Lox, respectively) were analyzed. The Lox gene was induced dramatically whereas expression of Npr1, a gene up-regulated by SA, decreased slightly in DN-AtRop1 transgenic plants after infection with $P$. infestans.
\end{abstract}

Conclusions: In conclusion, our results indicate that DN-AtROP1 affects potato resistance to $P$. infestans. This is associated with increased NADPH oxidase-mediated $\mathrm{H}_{2} \mathrm{O}_{2}$ production and JA signaling.

Keywords: AtRop1, Potato, Resistance, NADPH oxidase, $\mathrm{H}_{2} \mathrm{O}_{2}$ production, Jasmonic acid

\section{Background}

Potato (Solanum tuberosum) is the fourth largest crop in the world. Due to the high altitude, cold temperature and limited virus vectoring, Inner Mongolia has become the largest potato producing province in China. However, due to the absence of resistance genes to $P$. infestans in most cultivated potato varieties, potato late blight causes dramatic yield losses in Inner Mongolia $[1,2]$. Therefore, one of the major challenges for potato breeders is to decipher the resistance mechanisms to $P$. infestans and generate resistant cultivars through the combination of traditional and molecular breeding approaches. Numerous studies have investigated the molecular basis of quantitative resistance to pathogens [3],

\footnotetext{
*Correspondence: zhaojun02@hotmail.com

'Department of Agronomy, Inner Mongolia Agricultural University, Huhhot, Inner Mongolia 010019, China

Full list of author information is available at the end of the article
}

the identification of dominant resistance genes in potato $[4,5]$, the pathogen invasion mechanisms [6,7], as well as potato resistant signal molecules [6,8]. Previous studies also indicated that salicylic acid (SA), jasmonic acid (JA) and defense genes such as PR, StPK1, and StLRPK1 are involved in resistance to potato late blight [9-11]. However, an understanding of how small $G$ proteins regulate resistance to $P$. infestans in potato is lacking.

Small GTPases are monomeric guanine nucleotide binding proteins [12]. Rho GTPase, one branch of the small GTPase Ras superfamily, contains three related subfamilies: Rho, Rac, and Cdc42 [13,14]. In yeast and mammalian cells, Rho GTPases have multiple roles in plants, regulating the cytoskeleton reorganization, cell polarity, cell wall synthesis, hydrogen peroxide $\left(\mathrm{H}_{2} \mathrm{O}_{2}\right)$ production, cell cycle and differentiation [15-18]. Plants have evolved a distinct class of small GTPases named Rho-related GTPase (ROPs), which are very similar to Racs (a subfamily of Rho GTPase) from 
mammalian cells [19-21]. Plant ROPs not only exhibit high sequence similarity with mammalian Rho GTPases, but also possess similar functions $[20,22,23]$. Like their mammalian counterparts, ROPs are activated through guanine nucleotide exchange factors (GEFs) by exchanging GDP for GTP, whereas they are inactivated by GTPase-activating proteins (GAPs) and stimulate GTP hydrolysis to GDP. Guanine nucleotide dissociation inhibitors (GDIs) keep ROPs in an inactive form by inhibiting the release of GDP [19-21]. ROPs cycle between the GTP-binding form and the GDP-binding form, thus regulating a variety of cellular responses [24]. To date, several plant ROP genes have been identified, including the 11 Arabidopsis ROP genes [19,25,26], 7 rice genes and 9 maize genes [27]. The proteins encoded by these ROP genes regulate multiple signaling pathways, leading to a diverse array of cellular responses such as cell polarity/tip growth, cytoskeleton reorganization, secondary wall formation and plant defense $[20,22,23,28]$.

Rho-related GTPases are clearly involved in the establishment of plant defense. In rice, OsRac1 positively regulates the defense response to Magneporthe grisea via $\mathrm{H}_{2} \mathrm{O}_{2}$ accumulation, achieved through the regulation of $\mathrm{NADPH}$ oxidase activity [29-32]. OsRacB, OsRac4 and OsRac5 act as negative regulators in the establishment of resistance to rice blast [33-36], but OsRac6 regulated rice resistance in a positive manner [36]. In mammalian cells, overexpression of the dominant positive conformation of ZmRac (cloned from maize) also results in an increase in the production of superoxide and other ROS molecules [37]. Overexpressing the GhRac13 gene (from cotton) in Arabidopsis and HsRac1 (from humans) in soybean inhibits $\mathrm{H}_{2} \mathrm{O}_{2}$ production [38,39]. In Arabidopsis, AtROP2 and AtROP11 transgenic plants exhibit increased resistance to the Pseudomonas syringae pv. Tomato (Pst) DC3000 ( P. syringae). However, AtROP10 has the opposite effect on resistance to bacteria [40]. In barley, silencing $\mathrm{HvRacB}$ increases resistance to powdery mildew by reducing fungal haustorium establishment in a cell-autonomous and genotype-specific manner [41]. However, stable overexpression of CA-HvRACB, CAHvRAC1, and CA-HvRAC3 (active conformation) in barley led to enhanced susceptibility to powdery mildew $[33,42,43]$. In tobacco, overexpression of the MsRac1 gene results in cell death, thus leading to the development of brown necrotic lesions [44]. In addition, using the RNA interference silencing approach in Medicago truncatula plants indicates that MtROP9 plays a key role in ROS-mediated early infection signaling [45]. All of the above results demonstrate that ROPs play an important role (positively and negatively) on the establishment of plant defense.

Reactive oxygen species(ROS) including superoxide $\left(\mathrm{O}^{2-}\right)$, hydrogen peroxide $\left(\mathrm{H}_{2} \mathrm{O}_{2}\right)$, hydroxyl radical (HO.) and singlet oxygen $\left({ }^{1} \mathrm{O}_{2}\right)$, which generated by plasma membrane $\mathrm{NADPH}$ oxidases play pivotal roles in the defense response, and are thought to act as secondary messengers for the induction of resistance responses, such as the increased expression of defense genes and the induction of hypersensitive cell death known as the hypersensitive response (HR) $[46,47]$. Rapid production of ROS is one of the early events during incompatible interactions between plants and pathogens [46,48]. In Nicotiana benthamiana inhibiting ROS accumulation led to reduced resistance to $P$. infestans [47]. ROS in soybean cells may interact with nitric oxide to trigger the HR, thus effectively restricting pathogen growth [49]. In Arabidopsis, induction of ROS lead to the hypersensitive cell death response and enhanced its resistance to Pst and Hyaloperonospora arabidopsidis [50]. Increasing ROS production in rice induces HR-like responses, greatly contributing to reduction in the size of disease lesions caused by a virulent race of the rice blast fungus and altering expression of defense-related genes [51].

Many studies have shown that SA (salicylic acid) and JA (Jasmonic acid) are key signaling molecules which regulate plant resistance by inducing the expression of a series of defense genes,such as PR-1, PAD4, EDS1, and PDF1.2 [52]. SA plays a role in the establishment of resistance to biotrophic pathogen infection and systemic acquired resistance (SAR) [53]. The non-expressor of PR gene 1 (NPR1) is upregulated by SA accumulation during pathogen infection and is routinely used as a marker gene to track SAmediated signaling pathways [54]. A recent study established that $\mathrm{SA}$ is required for basal defense such as pathogen triggered immunity (PTI) in potato against $P$. infestans; SA reduction renders plants more susceptible to $P$. infestans possibly due to lower $P R$ gene expression [55]. Increasing SA levels in potato led to higher resistance to $P$. infestans [56]. JA is also believed to play an important role in the establishment of plant resistance to pathogens and in response to various stresses $[57,58]$. In plants, JA acts as a key signaling component involved in the establishment of induced systemic resistance (ISR) [59]. Lipoxygenase (Lox) is a key enzyme in the JA synthesis pathway, and the expression of the Lox gene is highly correlated with JA accumulation in response to various stresses [6]. Arabidopsis thaliana mutants impaired in the JA signaling pathway are always compromised in their resistance to necrotrophic pathogens [60]. JA acumulation was also observed after Pst DC3000 infection [59]. Silencing the allene oxide cyclase $(A O C)$ or OPDA reductase 3 (OPR3) genes, both coding for enzymes involved in JA biosynthesis, also perturbs the potato response to Pep13, a pathogen-associated molecular pattern (PAMP) from $P$. infestans, by reducing the accumulation of ROS and hypersensitive cell death. SA accumulation has been observed in JA deficient plants [6], indicating the existence of a cross talk between the JA and SA signaling pathways in the establishment of potato resistance. 
We analysed AtRop1, a small G protein in Arabidopsis and its role in the establishment of resistance to potato late blight. Our results demonstrate that transient or stable overexpression of an inactive form of AtRop1 (DN-AtRop1) enhances potato resistance to P. infestans infection, a resistance associated with the accumulation of $\mathrm{H}_{2} \mathrm{O}_{2}$ mediated by a NADPH oxidase homologue gene. This suggests that $\mathrm{H}_{2} \mathrm{O}_{2}$ plays a crucial role in AtRop1-mediated potato resistance to $P$. infestans infection. Additionally, preliminary results indicate the involvement of JA in AtRop1-mediated potato resistance to late blight.

\section{Results}

\section{Subcellular localization of AtRop1}

To determine the subcellular localization of AtRop1, a mGFP:AtRop1 construct was transiently expressed in tobacco epidermal cells and the GFP signal detected under fluorescence microscopy. As shown in Figure 1, the green signal was observed only on the plasma membranes (PM), while the GFP alone (as control) was visualized mainly in the cytoplasm. Hence, AtRop1 is localized at the PM.

Transient expression of a dominant inactive conformation of AtRop1 (DN-AtRop1) enhance potato resistance to

\section{$P$. infestans}

To determine the importance of AtRop1 in the potato response to P. infestans, Agrobacterium tumefaciens (LB4404) strains carrying either CA-AtRop1 (constitutively active) or DN-AtRop1 (dominant negative) were infiltrated into potato leaves. Twenty-four hours later, $P$. infestans $\left(5 \times 10^{5}\right.$ zoospore $/ \mathrm{mL}$ ) was inoculated at the infiltration sites and the lesion sizes were measured at different time points after inoculation. As shown in Figure 2A, lesions were observed on potato leaves 24 hours post-inoculation (hpi) and the size expanded gradually. Differences in lesion size were observed at $72 \mathrm{hpi}$ and $96 \mathrm{hpi}$. The lesions at the infiltration sites transiently expressing DN-AtRop1 were much smaller than lesions at the sites expressing CA-AtRop1 (Figure 2A). Quantification lesion size showed that the rate of lesion expansion after DN-AtRop1 infiltration was much slower compared with that at CA-AtRop1 infiltration sites (Figure 2B). These results suggest that AtRop1 may be involved in potato resistance to $P$. infestans.

To understand why transient expression of DN-AtRop1 inhibits lesion expansion on potato leaves, the development of $P$. infestans mycelium around the inoculation sites was firstly detected using trypan blue staining. As shown in Figure $2 \mathrm{C}$, compared to the sites of CA-AtRop1 expression, fewer mycelia were observed around the sites where DNAtRop1 was transiently expressed (Figure 2C). Importantly, significant mycelium development was observed at the sites of CA-AtRop1 expression and the control sites, however, fewer mycelia was detected at DN-AtRop1 expression sites, indicating that mycelium development was inhibited to a certain extent by DN-AtRop1 overexpression. Meanwhile, real-time PCR was performed to evaluate the biomass of $P$. infestans. This showed that $P$. infestans mycelium development at the CA-AtRop1 and DN-AtRop1 transient expression sites was significantly lower than control sites, with DN-AtRop1 expression sites showing the lowest biomass levels (Figure 2D). In conclusion, the small lesion size at DN-AtRop1 transient expression sites could be correlated with limited growth of $P$. infestans.

Next, we investigated the possible mechanisms underlying the inhibition of $P$. infestans development in potato after DN-AtRop1expression. Recent studies showed a tight link between ROPs and ROS accumulation [37]. This

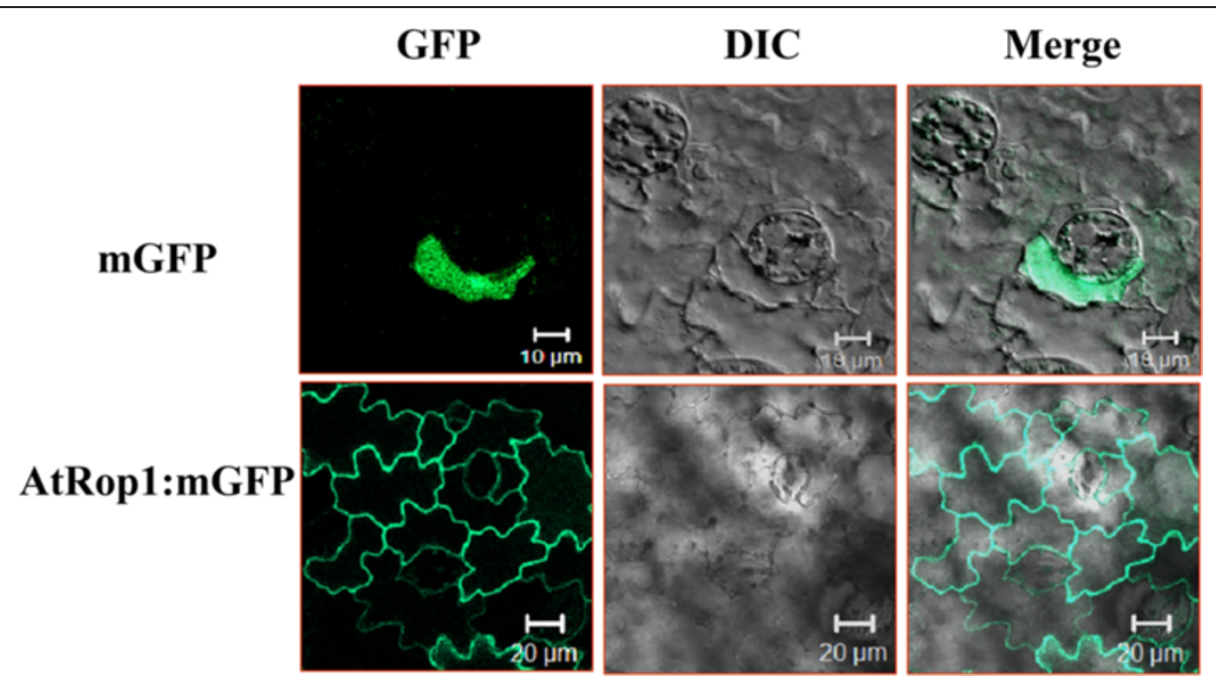

Figure 1 The subcellular localization of AtRop1. Transient expression of mGFP: AtRop1 in tobacco epidermal cells; differential interference contrast (DIC), refers to bright-field images of the cells. 

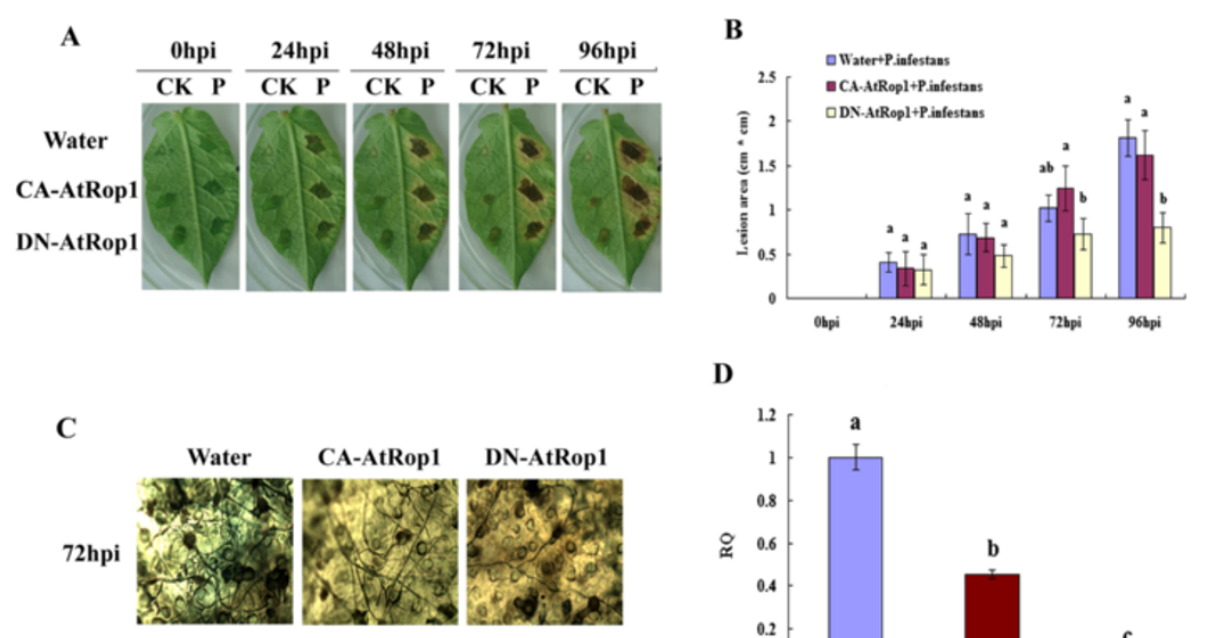

D

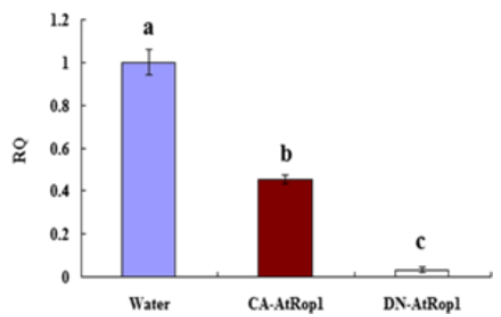

Figure 2 Transient expression of At-Rop1 negatively regulated potato resistance to $P$. infestans. Agrobacterium tumefaciens (LB4404) carrying CA-AtRop1 and DN-AtRop1 constructs were infiltrated into potato leaves at a concentration of $\mathrm{OD}_{600}=0.5$. A. Development of lesion size on potato leaves after inoculation with $P$. infestans $\left(5 \times 10^{5}\right.$ zoospore $\left./ \mathrm{mL}\right)$. The left part of the leaf was used as a control by inoculating with water; the right part was inoculated with $P$. infestans. B. After transient expression of CA-AtRop1 and DN-AtRop1, the lesion area (length by width) was measured at different time point after inoculation with $P$. infestans. Each value represents the average of three lesions $\left(\mathrm{cm}^{2} \pm\right.$ standard deviation). Levels not labeled with the same letter are significantly different at the $P<0.05$ level based on the ANOVA. $C$. The development of $P$. infestans mycelium at sites where CA-AtRop1 and DN-AtRop1 were transiently expressed was quantified by trypan blue staining. $\mathbf{D}$. The development of $P$. infestans at transient expression sites $72 \mathrm{hpi}$ was quantified by real-time PCR by comparing levels of the specific repetitive DNA sequence of $P$. infestans (as measure for fungal biomass) relative to potato EF-1a gene (for equilibration). Levels not labeled with the same letter are significantly different at the $P<0.05$ level based on the ANOVA. Bars represent averages with standard deviation of three technical replicates.

prompted us to analyze $\mathrm{H}_{2} \mathrm{O}_{2}$ accumulation by DAB staining at the P. infestans infection sites. At the DN-AtRop1 expression sites, $\mathrm{H}_{2} \mathrm{O}_{2}$ was observed $48 \mathrm{hpi}$, accumulated dramatically by $72 \mathrm{hpi}$ and was still at high levels at $96 \mathrm{hpi}$ (Figure 3A). However, this was not the case at the CAAtRoplexpression sites. In Figure 3B, quantification of $\mathrm{DAB}$ staining showed that both constructs led to increased $\mathrm{H}_{2} \mathrm{O}_{2}$ levels after inoculation with $P$. infestans. However, accumulation of $\mathrm{H}_{2} \mathrm{O}_{2}$ was much higher at the DN-AtRop1 expression sites than that at the CA-AtRop1 expression sites. We propose that the high level of $\mathrm{H}_{2} \mathrm{O}_{2}$ accumulation at DN-AtRop1 expression sites may be one of the causes of the increased resistance to P. infestans, illustrated by the inhibition of $P$. infestans development and the smaller lesion size on potato leaves.

\section{DN-AtRop1 enhances potato resistance to $P$. infestans}

To confirm the results observed in the transient expression system, we generated DN-AtRop1 transgenic potato lines via A. tumefaciens mediated transformation. The leaf disc method was used to generate transgenic lines, and positive transgenic lines were confirmed by Southern blot analysis (Figure 4A) and western blot using a commercial anti-GFP antibody (Figure 4B). DN-AtRop1 transgenic lines 6,8 and 11 were chosen for further functional analysis.
We first checked symptom development on transgenic potato leaves after inoculation with $P$. infestans. As shown in Figure 5B, when the control line showed discoloration symptoms $96 \mathrm{hpi}$, lesions had not appeared on the DN-AtRop1 transgenic potato leaves. Mycelium development on transgenic potato leaves was detected by trypan blue staining. The sparse mycelium of $P$. infestans was detected in DN-AtRop1 transgenic potato leaves at $96 \mathrm{hpi}$, whereas, the control leaves expressed the empty vector, showed a mass of blue staining under the microscope (Figure 5C). P. infestans biomass in DNAtRop1 transgenic potato leaves (lines 6, 8 and 11) was detected by real-time PCR. Quantitative analysis indicated reduced development of $P$. infestans in the three DN-AtRop1 transgenic lines compared to the control plants (Figure 5D), suggesting that the DN-AtRop1 transgene inhibits the development of $P$. infestans in potato leaves, thus increasing potato resistance to late blight.

\section{$\mathrm{H}_{2} \mathrm{O}_{2}$ is involved in potato AtRop1-mediated resistance to $P$. infestans}

In order to verify that $\mathrm{H}_{2} \mathrm{O}_{2}$ plays a key role in resistance of potato DN-AtRop1 transgenic lines to $P$. infestans, we analyzed $\mathrm{H}_{2} \mathrm{O}_{2}$ levels in the transgenic lines via DAB staining. Brown color was observed in DN-AtRop1 

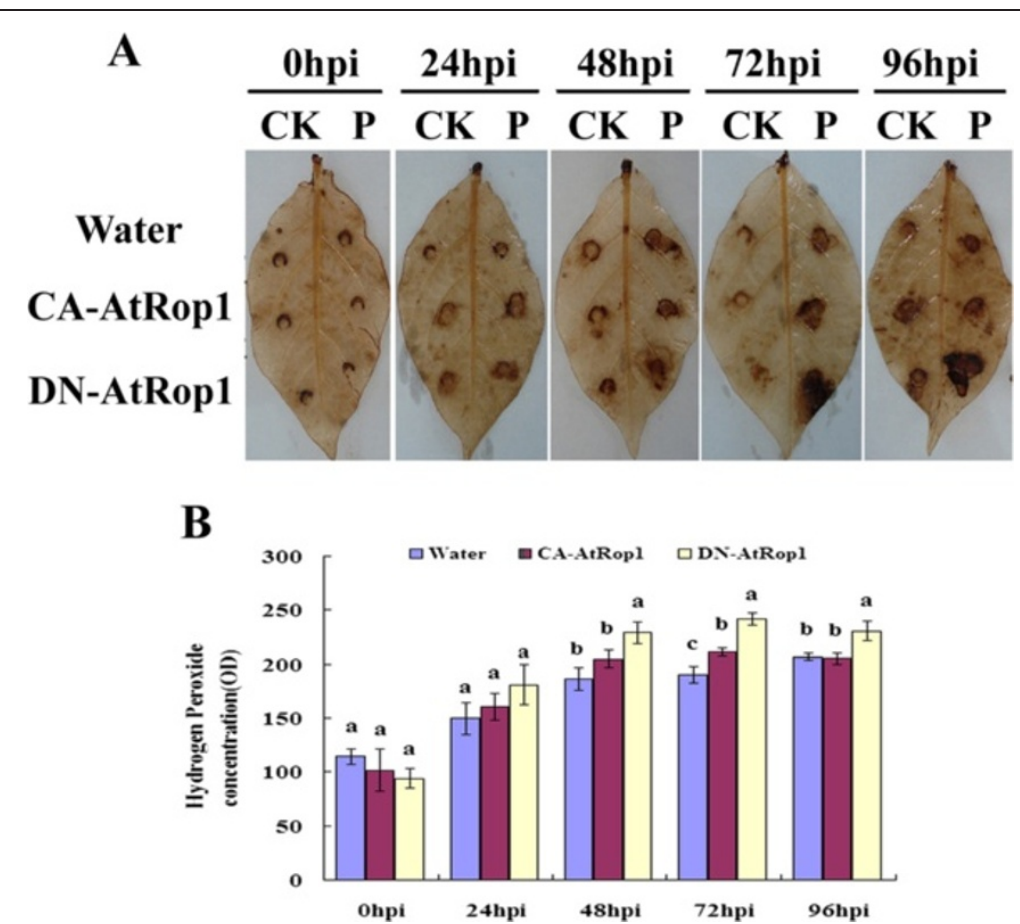

Figure 3 The accumulation of $\mathrm{H}_{2} \mathrm{O}_{2}$ at transient expression sites after inoculation with $P$. infestan. $A$. The accumulation of $\mathrm{H}_{2} \mathrm{O}_{2}$ was visualized by staining leaf segments transiently expressing CA-AtRop1 and DN-AtRop1 with diaminobenzidine (DAB) over time after inoculation with $P$. infestans. The right side of each leaf was inoculated with $P$. infestans, and the left side used as the control. B. The accumulation of $\mathrm{H}_{2} \mathrm{O}_{2}$ was quantified using the Quantity One (Bio-Rad) tool. Each value represents the average (centimeters ${ }^{2} \pm$ standard deviation) of three lesions. Levels not labeled with the same letter are significantly different at the $P<0.05$ level based on the ANOVA.

transgenic leaves at $24 \mathrm{hpi}$, whereas no signal was detected in control plants. Accumulation of $\mathrm{H}_{2} \mathrm{O}_{2}$ was observed in DN-AtRop1 transgenic plants at 48 hpi with higher levels at $72 \mathrm{hpi}$, while the control plants only showed a slight increased in brown color (Figure 6A). Quantification of $\mathrm{H}_{2} \mathrm{O}_{2}$ levels (based on the standard curve method of titanylsulfate) showed that the accumulation of $\mathrm{H}_{2} \mathrm{O}_{2}$ followed the same temporal pattern in the DN-AtRop1 and control lines, but levels were significantly higher in DN-AtRop1 transgenic lines (Figure 6B). Compared with control, all transgenic lines tested had higher $\mathrm{H}_{2} \mathrm{O}_{2}$ levels from 12hpi to 96hpi after inoculation suggesting
A

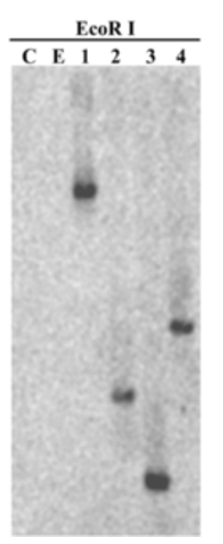

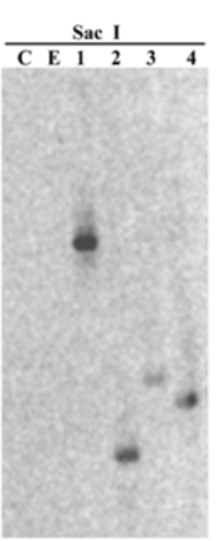

B

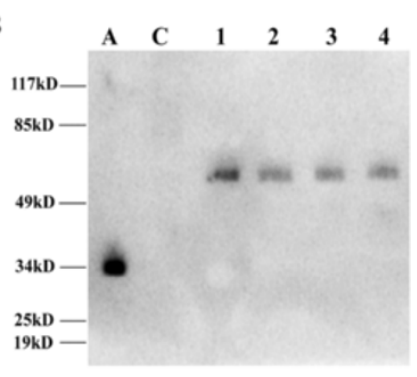

Figure 4 The identification of positive potato transgenic lines. A. Southern blot analysis of DN-AtRop1 transgenic lines with GFP probe. About $15 \mu \mathrm{g}$ of the genomic DNA was digested with EcoR I and Sac I, electrophoresed on a 1.0\% agarose gel, and blotted on to a positively charged nylon membrane. C: untransformed control plant, E: potato transformed with the empty vector p1300-221, 1-4: DN-AtRop1 potato transgenic lines $(6,7,8,11)$. B. Western blots analysis of the protein expression level of DN-AtROP1 in potato transgenic lines using an anti-GFP monoclonal antibody. A: positive control with only GFP protein, C: untransformed control plant. 1-4: DN-AtRop1 potato transgenic lines $(6,7,8,11)$. 
A

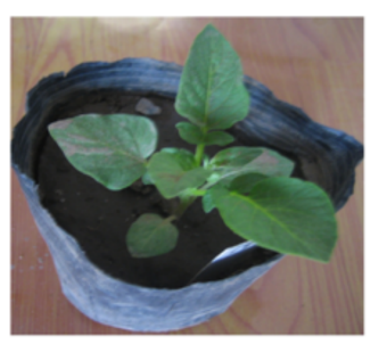

C

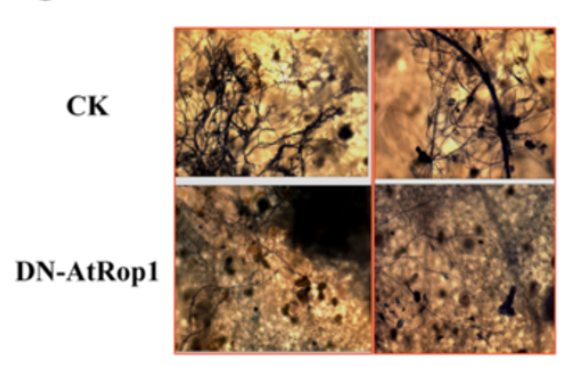

B

CK

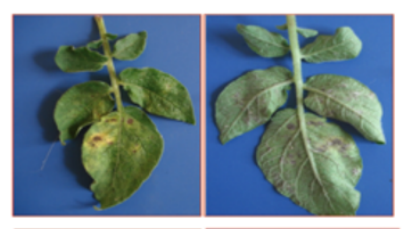

DN-AtRop1

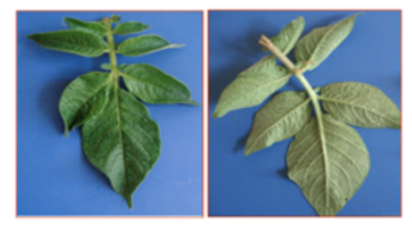

D

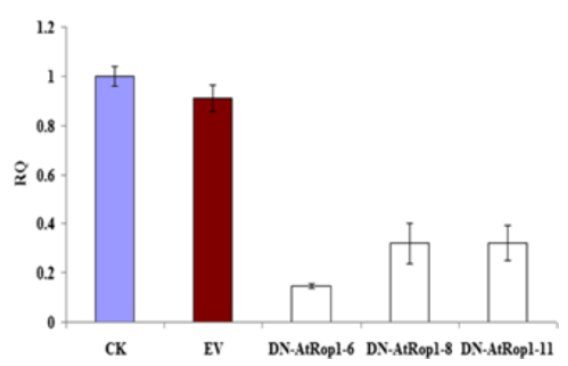

Figure 5 Resistance of potato AtRop1 (DN-AtRop1) transgenic lines to P. infestans. A. Four weeks old of transgenic (DN-AtRop1) potato.

B. Symptoms on detached leaves of the DN-AtRop1 transgenic line after infection with P. infestans. Photographed at 96 hpi. C. Mycelial development on the leaves of DN-AtRop1transgenic lines (line 6 and line 11) after 96 hpi. The mycelium was stained with trypan blue. D. Relative quantification (RQ) by real-time PCR of lesion sites by comparing levels of the $P$. infestans-specific repetitive DNA sequence (as measure for fungal biomass) relative to the potato EF-1a gene (for equilibration) at $96 \mathrm{hpi}$. Bars represent averages with standard deviation of three technical replicates. CK represents the wild-type potato and EV represents the potato transformed with the empty vector p1300-221.

\section{A}

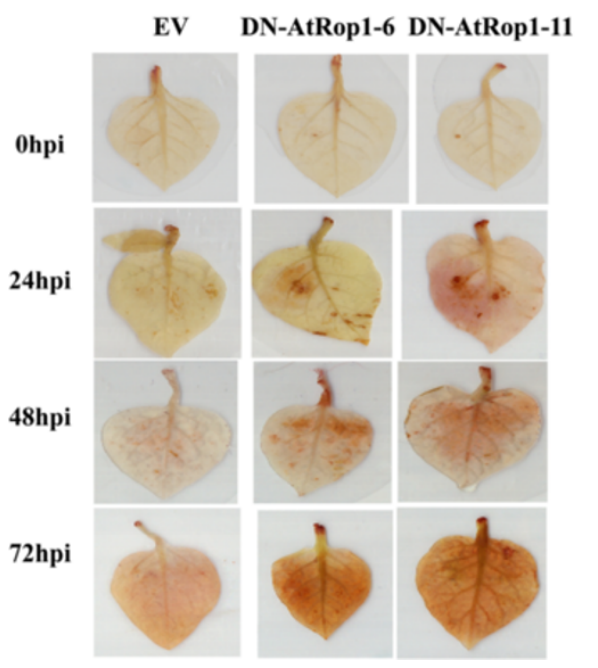

B

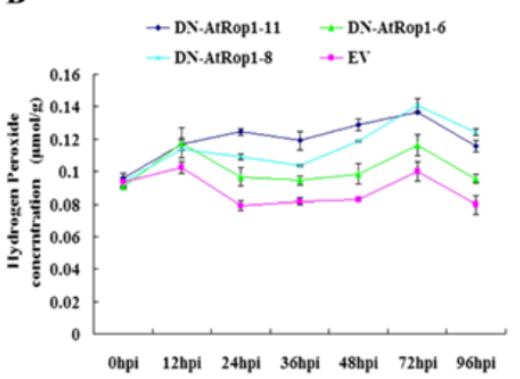

Figure $6 \mathrm{H}_{2} \mathrm{O}_{2}$ accumulation in DN-AtRop1 transgenic lines after infection with $P$. infestans. A. The accumulation of $\mathrm{H}_{2} \mathrm{O}_{2}$ was visualized by DAB staining on control and DN-AtRop1 transgenic plants at 0 hpi, 24 hpi, 48 hpi and 72 hpi. EV: transfomed with empty vector set up as control; DN-AtRop1-6 and DN-AtRop1-11 were two positive transgenic lines. B. The accumulation of $\mathrm{H}_{2} \mathrm{O}_{2}$ was quantified over time using a standard curve of titanylsulfate method. Each value is the mean of three replications of transgenic plants leaves of lines 6, 8 and 11. 
that AtRop1 negatively regulated potato resistance via $\mathrm{H}_{2} \mathrm{O}_{2}$ accumulation.

\section{AtRop1 negatively regulats $\mathrm{H}_{2} \mathrm{O}_{2}$ accumulation via a potato NADPH oxidase homologues}

We detected the accumulation of $\mathrm{H}_{2} \mathrm{O}_{2}$ after inoculation with $P$. infestans in DN-Rop1 transgenic lines. This data prompted us to check whether membrane-located Strboh (a NADPH oxidase homologue in potato) is the main regulator of $\mathrm{H}_{2} \mathrm{O}_{2}$ production in these transgenic lines. RT-PCR was performed using primers derived from Strboh-D, as shown in Figure 7A and B; transcript levels of Strboh-D were compared in DN-AtRop1 and control plants at different time points after inoculation (Figure 7B). In control plants, expression decreased by $24 \mathrm{hpi}$ and was not detected at $48 \mathrm{hpi}$. However, in DNAtRop1 transgenic plants, mRNA levels of Strboh-D gene remained constant at $24 \mathrm{hpi}$, decreasing slightly by $72 \mathrm{hpi}$, to almost half the control level by $96 \mathrm{hpi}$ (Figure 7A). These results suggest that the membrane localised Strboh-D gene may cause the accumulation of $\mathrm{H}_{2} \mathrm{O}_{2}$ in DN-AtRop1 transgenic lines after inoculation with $P$. infestans.

\section{JA may play a role in the resistance of DN-AtRop1 trans-} genic potato to $P$. infestans

SA and JA are major signaling hormones involved in the establishment of plant resistance to the pathogens. To check whether JA- and SA-dependent signaling pathways were involved in DN-AtRop1-associated resistance to $P$. infestans, we analyzed the transcript levels of SA and JA marker genes. These marker genes were Npr1, a central component of the SA signaling pathway and upregulated by SA accumulation, and Lox, which encodes a key enzyme in the JA biosynthetic pathway. As shown in Figure 8A and B, Lox transcript levels decreased dramatically in control plants by $24 \mathrm{hpi}$ and were not detectable at 96 hpi, whereas in DN-AtRop1 transgenic plants, Lox mRNA remained constant until 48 hpi and decreased gradually afterwards. The transcript profile of Npr1 was also studied. Quantification of expression data indicated that the Npr1 basal level in DN-AtRop1 plants was slightly lower than in control plants (Figure $8 \mathrm{C}$ ), and decreased further by 24 hpi after inoculation with $P$. infestans. These results indicated that JA signaling may be involved in AtRop1-mediated potato resistance to late blight.

\section{Discussion}

Subcellular localization of the AtRop1 protein

Using a transient expression system, the subcellular localization of AtROP1 was investigated using GFP tagging in tobacco epidermal cells. Our results showed that mGFP:AtRop1 was mainly localized at the PM (plasma membrane) (Figure 1). In mammalian and plant cells, $\mathrm{NADPH}$ oxidase is responsible for the generation of $\mathrm{H}_{2} \mathrm{O}_{2}$ and is also located at the PM [61,62]. This raises the possibility that AtROP1 may regulate a NADPH oxidase homologue at the PM, thus facilitating the accumulation of $\mathrm{H}_{2} \mathrm{O}_{2}$. The same result was obtained in rice, where OsRac1 is also located at the PM and regulates $\mathrm{H}_{2} \mathrm{O}_{2}$ production, thus enhancing rice resistance to $M$. grisea [29-31]. The PM is proposed to be the platform

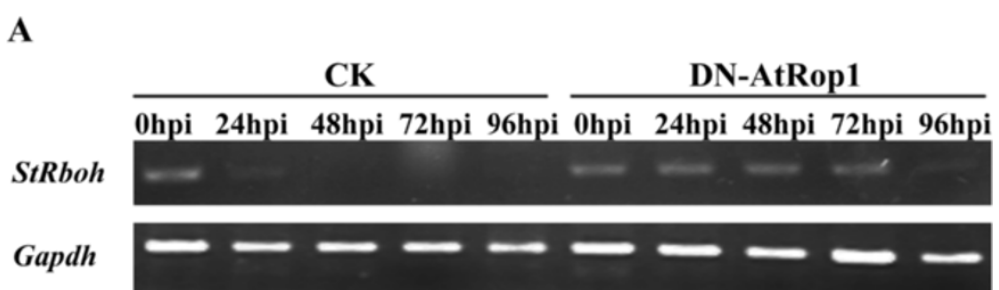

B

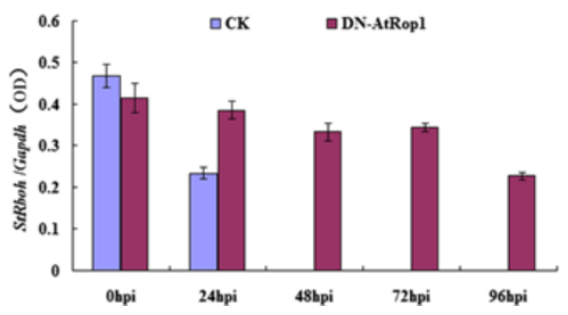

Figure 7 Transcript expression of the Strboh-D gene in DN-AtRop1 transgenic plants after inoculation with $P$. infestans. A. The transcript expression profile of the Strboh-D gene over time in DN-AtRop1 transgenic and control plants after $P$. infestans infection. Equal loading of cDNA was monitored by amplification of Gapdh. B. The relative expression level of the Strboh-D gene to Gapdh was quantified over time after inoculation with $P$. infestans. 


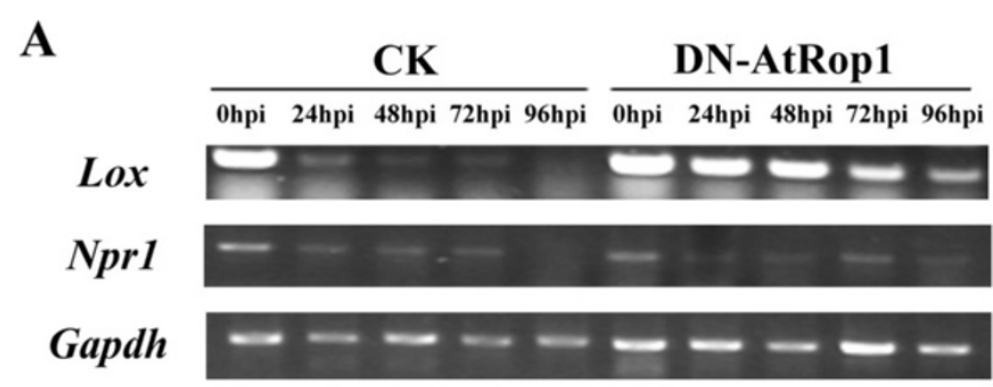

B

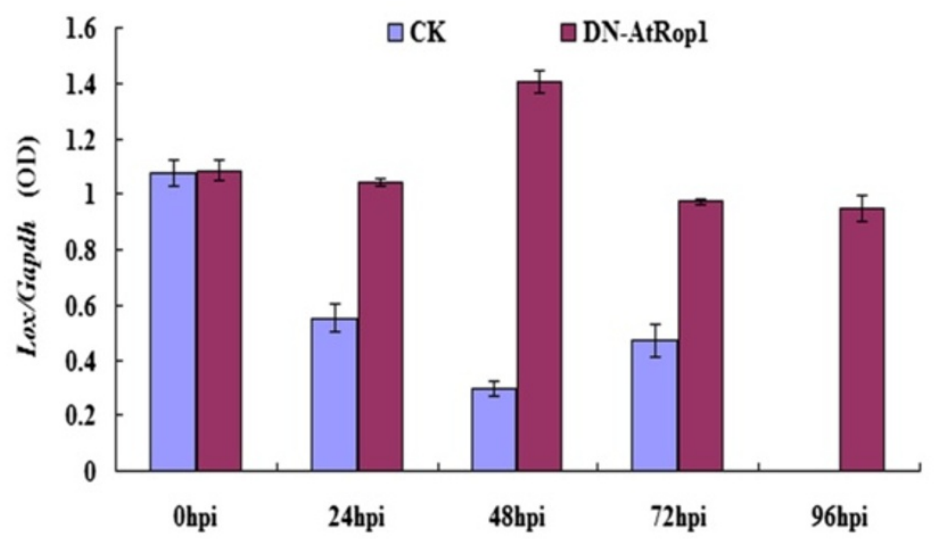

C

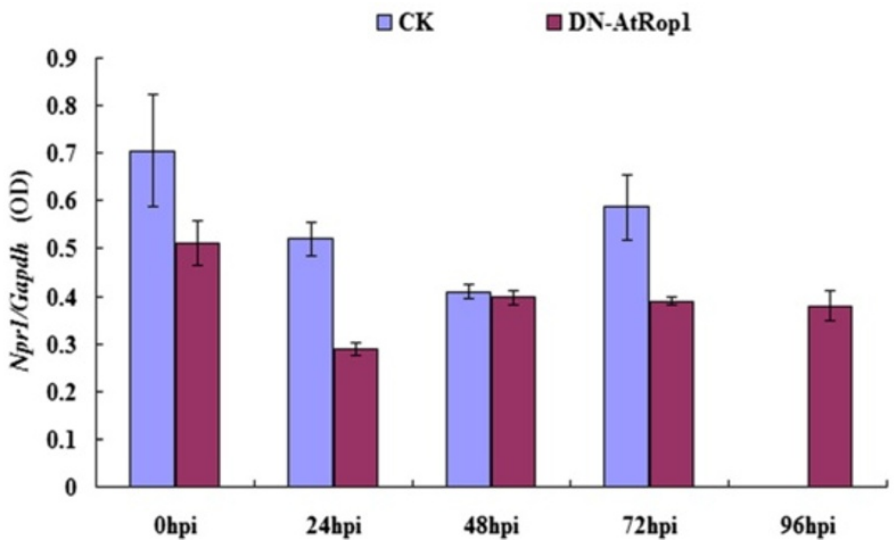

Figure 8 Transcript expression profile of the Lox and Npr1 genes in DN-AtRop1 transgenic plants after inoculation with $P$. infestans. A. Transcript expression profile of the Lox and Npr1 genes over time in DN-AtRop1 transgenic and control plants after P. infestans infection. Equal loading of CDNA was monitored by amplification of Gapdh. B. The relative expression level of the Lox gene to Gapdh was quantified over time. C. The relative expression level of the Nprl gene to Gapdh was quantified over time.

for conveying signal transduction from small G proteins to downstream factors, thus enhancing the establishment of potato defense responses.

\section{AtRop1 negatively regulates potato resistance to late} blight via accumulation of $\mathrm{H}_{2} \mathrm{O}_{2}$

Small GTPases of the RAC/ROP family play important roles in the establishment of plant defense responses [48,63]. In rice, overexpression of OsRac1 enhanced host resistance by increasing $\mathrm{H}_{2} \mathrm{O}_{2}$ levels [29,51]; silencing this gene in rice led to the development of larger lesions than in control plants after infection with a rice blast pathogen [64]. Further studies on OsRaclfunction revealed that a constitutively active form of OsRac1(CA-OsRac1) promotes $\mathrm{H}_{2} \mathrm{O}_{2}$ production [29], whereas a dominant negative form of OsRac1 ( $D N$ OsRac1) leads to the suppression of $\mathrm{H}_{2} \mathrm{O}_{2}$ [51]. Additionally, 
expressing dominant negative forms of human Rac1 (DN$h R a c 1)$ in soybean or OsRac1 in rice cell suspensions also leads to the suppression of $\mathrm{H}_{2} \mathrm{O}_{2}$ production in response to an elicitor treatment. This suggests the existence of a positive regulation mechanism by small $G$ proteins on plant resistance mediated by $\mathrm{H}_{2} \mathrm{O}_{2}$ accumulation $[39,51,65]$. However, small $\mathrm{G}$ proteins may play more complex roles indicated by the expression of a dominant negative form of OsRac1 (DN-OsRac1) in tobacco. This led to induced $\mathrm{H}_{2} \mathrm{O}_{2}$ accumulation after infection with Tobacco mosaic virus (TMV) [66] and overexpression of NtRac5 (Rac5 cloned from Nicotiana tabacum) in tobacco led to lower levels of $\mathrm{H}_{2} \mathrm{O}_{2}$ [67].We showed that the transient and stable expression of a dominant negative form of the Arabidopsis AtRop1 (DN-AtRop1) gene in potato led to a decrease in the development of $P$. infestans at the infection sites. This suggests a negative regulation mechanism of AtRop1 on potato resistance to late blight. $\mathrm{H}_{2} \mathrm{O}_{2}$ was found to be a key player in the signaling pathway associated with AtRop1-mediated potato resistance. The overexpression of a negative form of AtRop1 resulted in the accumulation of $\mathrm{H}_{2} \mathrm{O}_{2}$, and enhanced potato resistance to $P$. infestans infection. $\mathrm{H}_{2} \mathrm{O}_{2}$ is known to be a key player during the establishment of plant resistance $[48,63]$. The rapid production of $\mathrm{H}_{2} \mathrm{O}_{2}$, which triggers the HR in the infected areas, was observed in plants infected by non-host or avirulent strains of pathogens. In our study, overexpression of DN-AtRop1 promoted the accumulation of $\mathrm{H}_{2} \mathrm{O}_{2}$ after $P$. infestans infection, which possibly triggered an HR in the infected area, thus limiting the development of $P$. infestans, and resulting in smaller lesions (Figure 2 and Figure 5). Therefore the increase in $\mathrm{H}_{2} \mathrm{O}_{2}$ accumulation may result in enhanced resistance of transgenic potato lines to late blight. Our data are in perfect agreement with what was observed in tobacco lines overexpressing DN-OsRac1, which also exhibited smaller lesions after TMV infection [66].

\section{$\mathrm{H}_{2} \mathrm{O}_{2}$ accumulation in DN-AtRop1 transgenic lines is mediated by NADPH oxidase}

Generally, the production of $\mathrm{H}_{2} \mathrm{O}_{2}$ can be achieved either by mitochondrial electron transport during aerobic respiration or by oxidoreductases and metal-catalyzed oxidation. The activation of a membrane-associated NADPH oxidase constitutes the main source of $\mathrm{H}_{2} \mathrm{O}_{2}$ accumulation $[68,69]$. Strong induction of StRBOH which is a homologue of the NADPH oxidases catalytic subumit is observed not only in potato leaves, but also in potato tubers after infection with $P$. infestans [70]. In our study, sustained increased expression of StRboh in potato transgenic lines was observed after inoculation with $P$. infestans. However, its expression was suppressed dramatically in control plants. This indicates that the accumulation of $\mathrm{H}_{2} \mathrm{O}_{2}$ in the transgenic lines was likely to be caused by the sustained expression of the membrane-localisted StRboh.
Meanwhile, the plasma membrane localization of both AtRop1 and StRboh suggests that the PM may be the platform connecting AtRop1 and StRboh, thus facilitating the accumulation of $\mathrm{H}_{2} \mathrm{O}_{2}$. Catalase is a major $\mathrm{H}_{2} \mathrm{O}_{2}$ scavenging enzyme inside plant cells, and hydrolyses $\mathrm{H}_{2} \mathrm{O}_{2}$ into $\mathrm{H}_{2} \mathrm{O}$ and $\mathrm{O}_{2}$ to protect plant cells from deleterious effects of $\mathrm{H}_{2} \mathrm{O}_{2}$ [71]. However, we did not observe differences in the transcript levels of catalase between control and transgenic lines after infection with $P$. infestans (data not shown), suggesting that $\mathrm{H}_{2} \mathrm{O}_{2}$ accumulation is mainly caused by potato homologues of PM-localized NADPH oxidases.

\section{JA is involved in potato resistance regulated by AtRop1}

SA and JA are important signaling molecules in plant responses to pathogens. To check whether they were involved in the increased resistance of DN-AtRop1 transgenic lines to $P$. infestans, the transcript level of marker genes in these two pathways was estimated by RT-PCR. Our data showed that Lox gene expression was induced in DN-AtRop1 transgenic lines during $P$. infestans infection, indicating that the JA pathway was activated by DN-AtRop1 overexpression, whereas the SA signaling pathway was partially suppressed in this study.

Our data differ from previous reports showing that the SA signaling pathway was activated, and the JA signaling pathway was inhibited to a certain extent during $P$. infestans invasion of the resistant potato cultivar Zihuabai [72]. In addition, SA was found not only to regulate basal defense of potato against $P$. infestans, but was also involved in the establishment of systemic acquired resistance of potato induced by BABA [55,73]. However, Rosah and his colleague found that PAMP responses in potato required both $\mathrm{SA}$ and JA, indicating that JA is required for potato resistance establishment [6]. So, AtRop1 overexpression may activate PAMP-induced resistance pathways, thus enhancing potato resistance to $P$. infestans. A recent study established that JA and SA signaling pathways act antagonistically in potato [72]. The decreased Npr1 transcript levels and the concomitant increase in JA after inoculation with $P$. infestans suggest a conservation of the antagonistic effects of SA and JA. In addition to SA and JA, there are other hormones involved in plant resistance, such as ethylene (ET), brassinosteroids, Cytokinins (CKs), and auxin. Among them, the brassinosteroids and CKs were shown to enhance the plant resistance to pathogens through NPR1 [74-76], a master regulator in the SA signaling pathway. Ethylene was confirmed to be antagonistic to SA signaling pathway [52], while auxin may lead to enhanced susceptibility to biotrophic pathogens by affect SA biosynthesis [77]. Our data have shown that expressing DN-AtRop1 led to decreased Npr1 transcript levels after infection with $P$. infestans, indicating that AtRop1 may positively regulated the NPR1 expression in potato. 


\section{Conclusion}

We verified that AtRop1 could regulate potato resistance to late blight. The DN-AtRop1 appears to positively impact potato resistance to late blight, through activation of membrane-associated NADPH oxidase, thus facilitating $\mathrm{H}_{2} \mathrm{O}_{2}$ accumulation. We propose that $\mathrm{H}_{2} \mathrm{O}_{2}$ accumulation in turn limits $P$. infestans development, leads to smaller lesion size and enhances potato resistance to late blight. Our results also indicate that JA may be involved in AtRop1-mediated potato resistance to P. infestans.

\section{Methods}

\section{Plasmid construction}

The constructs pLG-CARop1, DNRop1 and Rop1, and the pBI121empty vector were kindly provided by Dr. Zhao Yan (Institute of Genetics and Developmental Biology, Chinese Academy of Sciences, Beijing). The constructs were digested with EcoRI and SacI, then blunt-end and ligated with the empty vector pBI121 to construct three expression vectors: pBIG-CARop1, pBIG-DNRop1 and pBIGRop1. The PCR identification of $A$. tumefaciens containing pBIG-CARop1, pBIG-DNRop1 and pBIG-Rop1 were performed by using the GFP primers $5{ }^{\prime}$-GAC GTA AAC GGC CAC AAG TT-3' and 5'-GAA CTC CAG CAG GAC CAT GT-3'.

\section{Subcellular localization of AtRop1}

Agrobacterium tumefaciens (strain LB4404) containing the expression vector (pBIG-CARop1/pBIG-DNRop1/ pBIG-Rop1) and the empty vector (GFP only) were grown for approximately $48 \mathrm{~h}$ in $5 \mathrm{ml} \mathrm{LB}$ medium contained $10 \mathrm{mM}$ MES (pH 5.7), $20 \mu \mathrm{M}$ acetosyringone and $100 \mathrm{mg} / \mathrm{L}$ rifampicin. Agrobacterium were collected and resuspended in $5 \%$ sucrose at a concentration of $\mathrm{OD}_{600}=2.0$, followed by infiltration into tobacco leaves using a syringe without the needle. After transient expression, the tobacco leaves were placed in the dark for $72 \mathrm{~h}$. The GFP signal was detected in tobacco epidermal cells via confocal microscope (Carl Zeiss LSM-510).

\section{Preparation of zoospore suspensions of $P$. infestans}

Phytophthora infestans mating type A1 was kindly provided by Prof. Zhang Ruofang (Potato Engineering Center of Inner Mongolia University). After culturing on sterilized oat grains at $18^{\circ} \mathrm{C}$ for $2-3$ weeks, the sporangia of $P$. infestans were washed with sterile water and kept at $4^{\circ} \mathrm{C}$ for $4-6$ hours to facilitate zoospore release. Zoospores were filtered through 1-2 layers of sterilized gauze, and the concentration determined using a haemocytometer under the microscope. The solution of zoospores was diluted to $5 \times 10^{5}$ zoospore $/ \mathrm{mL}$ for all inoculations [3].

The potato leaves were inoculated with $20 \mu \mathrm{L}$ zoospore suspension $\left(5 \times 10^{5} / \mathrm{mL}\right)$ and incubated at $20^{\circ} \mathrm{C}$ with $85 \%$ humidity for resistance evaluation and determination of $\mathrm{H}_{2} \mathrm{O}_{2}$ accumulation [78]. Zoospore suspensions were also spread onto the abaxial surface of transgenic potato leaves with a sterile brush and kept at $20^{\circ} \mathrm{C}$ to detect $\mathrm{H}_{2} \mathrm{O}_{2}$ production and assays of mycelium biomass.

Agrobacterium tumefaciens mediated transient expression Agrobacterium tumefaciens (strain LB4404) carrying the AtRop1 mutants (CA-AtRop1 and DN-AtRop1) were grown for approximately $48 \mathrm{~h}$ in LB medium contained $10 \mathrm{mM}$ MES (pH 5.7) and $20 \mu \mathrm{M}$ acetosyringone. Following centrifugation, bacteria were resuspended in a infiltration medium that contained $10 \mathrm{mM} \mathrm{MgCl} 2,10 \mathrm{mM}$ MES ( $\mathrm{pH}$ 5.7) and $150 \mu \mathrm{M}$ acetosyringone at a concentration of $\mathrm{OD}_{600}=0.5$ (optical density $600 \mathrm{~nm}$ ). The bacteria were infiltrated into detached potato leaves using a syringe without needle. Twenty-four hours later, $20 \mathrm{Ml}$ of the zoospore suspension $\left(5 \times 10^{5} / \mathrm{mL}\right)$ was inoculated at the infiltration sites. The resistance of potato to $P$. infestans was evaluated using lesion area of the inoculated leaves at different time points. Lesion area was estimated by counting the length $\times$ width of the lesion. Every experiment was repeated three times.

\section{Quantitative and qualitative determination of $\mathrm{H}_{2} \mathrm{O}_{2}$ production}

The staining method 3, 3 '-diaminobenzidine (DAB) was used to detect the accumulation of $\mathrm{H}_{2} \mathrm{O}_{2}$. The DAB solution was freshly prepared to avoid auto-oxidation. Leaf segments were floated in $0.1 \%(\mathrm{w} / \mathrm{v}) \mathrm{DAB}$ solution (pH 3.8) and kept at $25^{\circ} \mathrm{C}$ in dark. After $8 \mathrm{~h}$, the leaves were transferred into $95 \%$ ethanol and bleached by boiling for $30 \mathrm{~min}$. Leaves were then stored in glycerolethanol $(1 / 4 \mathrm{v} / \mathrm{v})$ solution until photographed. The brown color due to $\mathrm{DAB}$ polymerization represented the accumulation level of $\mathrm{H}_{2} \mathrm{O}_{2}$ [79]. Color quantification data of DAB was evaluated by Quantity One (Bio-Rad, American) tools.

The titanium sulfate standard curve method was used to quantify the concentration of $\mathrm{H}_{2} \mathrm{O}_{2}$. The $\mathrm{H}_{2} \mathrm{O}_{2}$ and titanium sulfate generated yellow peroxidate- $\mathrm{Ti}$ compound precipitate. This problem was solved by treating with sulphuric acid; the color represents the concentration of $\mathrm{H}_{2} \mathrm{O}_{2}$, Values were collected at $\mathrm{OD}_{415} \mathrm{~nm}$ and were linearly related to $\mathrm{H}_{2} \mathrm{O}_{2}$ concentration [80]. To generate the standard curve of $\mathrm{H}_{2} \mathrm{O}_{2}, 30 \%$ standard $\mathrm{H}_{2} \mathrm{O}_{2}(0,0.1,0.2,0.4,0.6,0.8,1.0 \mu \mathrm{M})$ was reacted with $5 \%$ titanium sulfate $(\mathrm{w} / \mathrm{v})$ in reaction buffer that contained ammonia and acetone, then solved with $2 \mathrm{M}$ sulphuric acid. The regression equation was obtained through the formula: $\mathrm{Y}=0.8144 \mathrm{X}+0.025, \mathrm{R}^{2}=0.9953$ by using values collected at $\mathrm{OD}_{415} \mathrm{~nm}$ through spectrophotometry(TU-1901)and used as standard curve. Then, $0.1 \mathrm{~g}$ of ground potato leaves were collected at $0,24,36$, 
48, 72 and $96 \mathrm{hpi}$, in liquid nitrogen and the powder transferred into $1.5 \mathrm{~mL}$ centrifuge tubes containing $1 \mathrm{~mL}$ prechilled acetone $\left(4^{\circ} \mathrm{C}\right)$ to extract $\mathrm{H}_{2} \mathrm{O}_{2}$. After centrifugation for $10 \mathrm{~min}$ at $6000 \mathrm{rpm}$, the $100 \mu \mathrm{L}$ supernatant was used to react with $5 \%$ titanium sulfate $(\mathrm{w} / \mathrm{v})$. After the mixture was solved in $2 \mathrm{M}$ sulphuric acid, the $\mathrm{H}_{2} \mathrm{O}_{2}$ concentration over time $(0,12,24,36,48,72$ and $96 \mathrm{hpi}$ ) was detected using a UV Spectrophotometer at $\mathrm{OD}_{415} \mathrm{~nm}$.

\section{Trypan blue staining to detect mycelium development}

Trypan blue staining was used to detect the development of $P$. infestans mycelium. Infected potato leaf segments were transferred into $95 \%$ ethanol and boiled for $30 \mathrm{~min}$ to bleach the leaves. Leaves were then infiltrated with $0.5 \%(\mathrm{w} / \mathrm{v})$ trypan blue solution for 4 hours at $25^{\circ} \mathrm{C}$. After washing the samples with water for three times, the mycelium was visualized under the microscope [81].

Quantify the development of $P$. infestans on potato leaves Quantitative real time PCR was applied to determine the growth of $P$. infestans on potato plants using a lightcycler 480II(Roche, American) in combination with the qPCR kit SYBR Select Master Mix (ABI, American). DNA was extracted by using the hexa-decyl tri-methyl ammonium bromide (CTAB) method [82]. The primer PIO8-3-3F (5CAA TTC GCC ACC TTC TTC GA-3) and PIO8-3-3R (5-GCC TTC CTG CCC TCA AGA AC-3) was used to amplify and detect a P.infestans-specific repetitive DNA sequence [83] and primer StEF-1-F(5-GTG TGT TAC GAG AAC TTG CTT TAC T-3) and StEF-1-R(GGA ACT ATG TAT TTT GCC ACC GTC CTG) was used to amplify potato $E F-1 \alpha$ gene as an endogenous control.

\section{Plant materials and transformation}

Potato plants Solanum tuberosum cv "Shepody" were grown on Murashige and Skoog (MS) medium in vitro at a photo flux density of $3000-4000 \mathrm{Lx}, 60-85 \%$ relative humidity, and a $16 \mathrm{~h} / 12 \mathrm{~h}$ day and night cycle at $25^{\circ} \mathrm{C}$. A single colony of Agrobacteria LB4404 was cultured in a shaker culture of $10 \mathrm{~mL}$ of LB medium containing kanamycin $(100 \mathrm{mg} / \mathrm{L})$ and rifampin $(100 \mathrm{mg} / \mathrm{L})$ and kept at $28^{\circ} \mathrm{C}$, $220 \mathrm{rpm}$ for $48 \mathrm{~h}$. The leaf veins of $3 \sim 4$ weeks old potato seedlings leaves were cut, then floated in MS liquid medium that contained bacterial suspension (the bacterial concentration was $\mathrm{OD}_{600}=0.5$ ) and kept in the dark for 23 days. The leaves were transferred onto MS solid medium after drying on sterile filter paper. After 2 days, the leaves were transformed onto MS medium contained $0.5 \mathrm{mg} / \mathrm{L}$ indolylacetic acid (IAA), $2.0 \mathrm{mg} / \mathrm{L}$ 6-benzyl aminopurine (6-BA), $2.5 \mathrm{mg} / \mathrm{L}$ gibberellic acid (GA3), $25 \mathrm{mg} / \mathrm{L}$ hygromycin and $500 \mathrm{mg} / \mathrm{L}$ cefotaxime to induce adventitious buds. Four weeks later, regenerated potato shoots were grown on regeneration medium containing $25 \mathrm{mg} / \mathrm{L}$ hygromycin and
$500 \mathrm{mg} / \mathrm{L}$ cefotaxime for selection. The transgenic plants were identified by Southern blot and Western blot.

\section{Southern blot analysis}

Potato genomic DNA was extracted using the CTAB method [82]. For DNA extraction, $0.2 \mathrm{~g}$ of freshly harvested leaves was ground in liquid nitrogen. The powder was suspended in $1 \mathrm{~mL}$ of DNA extraction buffer $(50 \mathrm{mM}$ Tris- $\mathrm{HCl} \mathrm{pH}$ 8.0, $10 \mathrm{mM}$ EDTA, $700 \mathrm{mM} \mathrm{NaCl}, 1 \%$ CTAB solution, $0.5 \% \mathrm{PVP}$ ) and incubated at $65^{\circ} \mathrm{C}$ for 30 minutes. DNA was extracted by mixing with an equal volume of chloroform: isoamyl alcohol (24:1) and centrifuged at $12,000 \mathrm{rpm}$ for $10 \mathrm{~min}$ at $4^{\circ} \mathrm{C}$. The supernatant was removed to a fresh tube and precipitated overnight with equal volumes of ice-cold isopropanol and 0.1 volume $3 \mathrm{M}$ sodium acetate in $-20^{\circ} \mathrm{C}$. The mixture was centrifuged at $12,000 \mathrm{rpm}$ for $10 \mathrm{~min}$ at $4{ }^{\circ} \mathrm{C}$. The pellet was washed with $70 \%$ ethanol twice, then dried completely and dissolved in TE buffer. DNA was purified with RNAse and quantified by UV Spectrophotometry.

The GFP probe for Southern blotting was generated according to the instruction of DIG DNA Labeling and Detection Kit II (Roche, American) based on its sequence. After genomic DNA was digested with EcoR I and Sac I, the products were separated on $1.0 \%$ agarose gels, then transferred onto a nylon membrane. The membrane was washed with $2 \times \operatorname{SSC}(0.3 \mathrm{M} \mathrm{NaCl}, 30 \mathrm{mM}$ citrate sodium, $\mathrm{pH} 7.0$ ), then twice with $0.1 \%$ SDS ( $5 \mathrm{~min}$ ), followed by washing twice with $0.5 \times \mathrm{SSC}$ once and twice with $0.1 \%$ SDS $(15 \mathrm{~min})$ at $65^{\circ} \mathrm{C}$. The membrane was baked at $80^{\circ} \mathrm{C}$ for $2 \mathrm{~h}$ to cross-link the DNA with the nylon membrane. The hybridization of the membrane with the labeled GFP probe was performed overnight in hybridization buffer (provided by DIG DNA Labeling and Detection Kit II) at $42^{\circ} \mathrm{C}$. After hybridization, the membrane was washed with washing buffer $(0.1 \mathrm{M}$ maleic acid, $0.15 \mathrm{M} \mathrm{NaCl}, 0.3 \%$ Tween 20, pH 7.5) for $5 \mathrm{~min}$; followed by incubation with blocking solution (provided by DIG DNA Labeling and Detection Kit II) for $30 \mathrm{~min}$. The membrane was then incubated with Anti-Digoxigenin-AP (1:5000 dilutions) for $30 \mathrm{~min}$. The membrane was washed with washing buffer twice, and equilibrated in detection buffer $(0.1 \mathrm{M}$ Tris$\mathrm{HCl}, 0.1 \mathrm{M} \mathrm{NaCl}, \mathrm{pH}$ 9.5) for $5 \mathrm{~min}$. The membrane was stained with $1 \mathrm{ml} \mathrm{CSPD}$, and incubated at $25^{\circ} \mathrm{C}$ for $5 \mathrm{~min}$, then analysed ueing a Chemi XT4 (Syugene, American).

\section{Western-blot analysis}

Transgenic potato leaves were ground in liquid nitrogen and the powder transferred into $1 \mathrm{~mL}$ protein isolation buffer ( $\mathrm{pH}$ 6.0), which contained $5 \mathrm{mM} \mathrm{K}_{3} \mathrm{PO}_{4}, 2.5 \%$ sucrose, $0.1 \% \beta$-mercaptoethanol, and $0.5 \mathrm{mM}$ phenylmethyl sulfonylfluoride. The crude extract was centrifuged at $4^{\circ} \mathrm{C}$, $12,000 \mathrm{rpm}$ for $20 \mathrm{~min}$. The supernatant was collected and mixed with loading buffer. Proteins were separated by 
SDS-PAGE and transferred to a nitrocellulose membrane. The nitrocellulose membrane was blocked with $5 \%$ non-fat dry milk in PBST(Phosphate Buffered Saline Tween-20) buffer and incubated with an anti-GFP monoclonal antibody (1:5000 dilution, Sangon, China) and HRP-conjugated anti-rat secondary antibody (1:3000 dilution, Sangon, China) to detect the signal by Chemi XT4 (Syugene, American).

\section{RT-PCR}

Total RNA was extracted from potato transgenic leaves using the RNA iso Reagent (TaKaRa, Japan). The quality of RNA was examined on a $1.2 \%$ agarose gel. The cDNA for RT-PCR was generated using AMV transcriptase (TaKaRa, Japan) according to the manufacturer's instructions. The specific primers used for RT-PCR analysis were as follows:

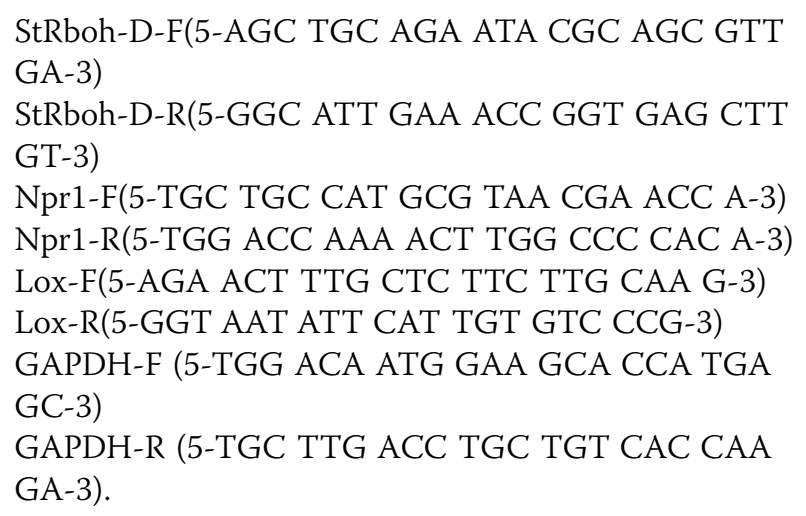

\section{Competing interests}

The authors declare that they have no competing interests.

\section{Authors' contributions}

JZ conceived and designed the experiments. ZZ FY RN XZ performed the experiments. SY JG analyzed the data. YZ MF contributed reagents/materials/ analysis tools. ZZ wrote the paper. All authors read and approved the final manuscript.

\section{Acknowledgment}

We would like to thank Professor Zhang Ruofang (Potato Engineering Center of Inner Mongolia University) for kindly providing the $P$. infestans strain. This work was supported by the National Nature Science Foundation of China (30760132 and 31260425).

\section{Author details}

'Department of Agronomy, Inner Mongolia Agricultural University, Huhhot, Inner Mongolia 010019, China. ${ }^{2}$ Institutes of Genetics and Developmental Biology, Chinese Academy of Science, Beijing 100101, China.

Received: 25 August 2014 Accepted: 19 December 2014 Published online: 30 December 2014

\section{References}

1. Zhao ZZ, Sun X: Research status and control strategy of potato late blight. China Plant Prot 2009, 8:12-14.

2. Sun ZK, Niu C, Yang SS: Research of potato late blight. Life Sci Res 2006, S1:71-75.

3. Wang BL: Induced Expression Profiling of Potato Genes Associated with Quantitative Resistance to Late Blight and Preliminary Exploring of Quantitative Resistance Mechanism. Wuhan: Huazhong Agricultural University; 2005.
4. Fry WE, Goodwin SB: Resurgence of the Irish potato famine fungus. Bioscienece 1997, 47:363-371.

5. Vleeshouwers VG, Van Dooijeweert W, Govers F, Kamoun S, Colon LT: The hypersensitive response is associated with host and nonhost resistance to Phytophthora infestans. Planta 2000, 210(6):853-864.

6. Halim VA, Altmann S, Ellinger D, Eschen-Lippold L, Miersch O, Scheel D, Rosahl S: PAMP-induced defense responses in potato require both salicylic acid and jasmonic acid. Plant J 2009, 57:230-242.

7. Halim VA, Hunger A, Macioszek V, Landgraf P, Nürnberger T, Scheel D, Rosahl S: The oligopeptide elicitor Pep-13 induces salicylic aciddependent and -independent defense reactions in potato. Physiol Mol Plant Pathol 2004, 64(6):311-318.

8. Yamamizo C, Kuchimura K, Kobayashi A, Katou S, Kawakita K, Jones JDG, Noriyuki D, Hirofumi Y: Rewiring mitogen-activated protein kinase cascade by positive feedback confers potato blight resistance. Plant Physiol 2006, 140:681-692.

9. Shibata Y, Kawakita K, Takemoto D: Age-related resistance of Nicotiana benthamiana against hemibiotrophic pathogen Phytophthora infestans requires both ethylene and salicylic acid-mediated signaling pathways. Mol Plant Microbe Interact 2010, 23(9):1130-1142.

10. Shi X, Tian Z, Liu J, van der Vossen EA, Xie C: A potato pathogenesisrelated protein gene, StPRp27, contributes to race-nonspecific resistance against Phytophthora infestans. Mol Biol Rep 2012, 39(2):1909-1916.

11. Cohen Y, Gisi U, Niderman T: Local and systemic protection against Phytop hthor a infestans induced in potato and tomato plants by jasmonic acid and jasmonic methyl ester. Phytopathology 1993, 83 (10):1054-1062.

12. Parada LF, Tabin CJ, Shih C, Weinberg RA: Human EJ bladder carcinoma oncogene is homologue of Harvey carcoma virus Ras gene. Nature 1982, 291(5866):474-478.

13. Hall A: Rho GTPases and the actin cytoskeleton. Science 1998, 279:509514.

14. Chant J, Stowers L: GTPase cascades choreographing cellular behavior: movement, morphogenesis and more. Cell 1995, 81:1-4.

15. Takai Y, Sasaki T, Matozaki T: Small GTP-binding proteins. Physiol Rev 2001, 81(1):153-208

16. Settleman J: Rac'n Rho: the music that shapes a developing embryo. Dev Cell 2001, 1(3):321-331.

17. Hall A, Nobes CD: Rho GTPases: molecular switches that control the organization and dynamics of the actin cytoskeleton. Philos Trans R SoC Lond B Biol Sci 2000, 355:965-970.

18. Chen $X$, Friml J: Rho-GTPase-regulated vesicle trafficking in plant cell polarity. Biochem Soc Trans 2014, 42(1):212-218.

19. Zheng ZL, Yang ZB: The Rop GTPase: an emerging signaling switch in plants. Plant Mol Biol 2000, 44:1-9.

20. Yang ZB: Small GTPase: versatile signaling switches in plants. Plant Cell 2002, 14(Suppl):S375-S388.

21. Vernoud V, Horton AC, Yang ZB, Nielsen E: Analysis of the small GTPase gene superfamily of Arabidopsis. Plant Physiol 2003, 131(3):1191-1208.

22. Gu Y, Wang Z, Yang Z: ROP/RAC GTPase: an old new master regulator for plant signaling. Curr Opin Plant Biol 2004, 7:527-536.

23. Xu J, Scheres B: Cell polarity: ROPing the ends together. Curr Opin Plant Biol 2005, 8(6):613-618

24. Craddock C, Lavagi I, Yang Z: New insights into Rho signaling from plant ROP/Rac GTPases. Trends Cell Biol 2012, 22:492-501.

25. Bischoff F, Molendijk A, Rajendrakumar CS, Palme K: GTP-binding proteins in plants. Cell Mol Life Sci 1999, 55:233-256.

26. Winge P, Brembu T, Kristensen R, Bones AM: Genetic structure and evolution of RAC-GTPases in Arabidopsis thaliana. Genetics 2000, 156 (4):1959-1971

27. Christensen TM, Vejlupkova Z, Sharma YK, Arthur KM, Spatafora JW, Albright CA, Meeley RB, Duvick JP, Quatrano RS, Fowler JE: Conserved subgroups and developmental regulation in the monocot rop gene family. Plant Physiol 2003, 133:1791-1808.

28. Humphries JA, Vejlupkova Z, Luo A, Meeley RB, Sylvester AW, Fowler JE, Smith LG: ROP GTPases act with the receptor-like protein PAN1 to polarize asymmetric cell division in maize. Plant Cell 2011, 23(6):2273-2284

29. Kawasaki T, Henmi K, Ono E: The small GTP-binding protein rac is a regulator of cell death in plants. Proc Natl Acad Sci U S A 1999, 96:10922-10926. 
30. Kawasaki T, Koita H, Nakatsubo T, Hasegawa K, Wakabayashi K, Takahashi H, Umemura K, Umezawa T, Shimamoto K: Cinnamoyl-CoA reductase, a key enzyme in lignin biosynthesis, is an effector of small GTPase Rac in defense signaling in rice. Proc Natl Acad Sci U S A 2006, 103(1):230-235.

31. Ono E, Wong HL, Kawasaki T, Hasegawa M, Kodama O, Shimamoto K: Essential role of the small GTPase Rac in disease resistance of rice. Proc Natl Acad Sci U S A 2001, 98(2):759-764.

32. Oda T, Hashimoto H, Kuwabara N, Akashi S, Hayashi K, Kojima C, Wong HL, Kawasaki T, Shimamoto K, Sato M, Shimizu T: Structure of the N-terminal regulatory domain of a plant $\mathrm{NADPH}$ oxidase and its functional implications. J Biol Chem 2010, 285(2):1435-1445.

33. Schultheiss H, Hensel G, Imani J, Broeders S, Sonnewald U, Kogel KH, Kumlehn J, Hückelhoven R: Ectopic expression of constitutively activated RACB in barley enhances susceptibility to powdery mildew and abiotic stress. Plant Physiol 2005, 139(1):353-362.

34. Schultheiss H, Preuss J, Pircher T, Eichmann R, Hückelhoven R: Barley RIC171 interacts with RACB in planta and supports entry of the powdery mildew fungus. Cell Microbio/ 2008, 10(9):1815-1826.

35. Jung YH, Agrawal GK, Rakwal R, Kim JA, Lee MO, Choi PG, Kim YJ, Kim MJ, Shibato J, Kim SH, Iwahashi H, Jwa NS: Functional characterization of OsRacB GTPase-a potentially negative regulator of basal disease resistance in rice. Plant Physiol Biochem 2006, 44(1):68-77.

36. Chen L, Shiotani K, Togashi T: Analysis of the Rac/Rop small GTPase family in rice: expression, subcellular localization and role in disease resistance. Plant Cell Physiol 2010, 51(4):585-595.

37. Hassanain HH, Sharma Y, Moldovan L, Khramtsov V, Berliner LJ, Duvick JP, Goldschmidt-Clermont PJ: Plant rac proteins induce superoxide production in mammalian cells. Biochem Biophys Res Commun 2000, 272:783-788.

38. Potikha TS, Collins CC, Johnson DI, Delmer DP, Levine A: The involvement of hydrogen peroxide in the differentiation of secondary walls in cotton fibers. Plant Physiol 1999, 119(3):849-858.

39. Park J, Choi HJ, Lee S, Lee T, Yang Z, Lee Y: Rac-related GTP-binding protein in elicitor-induced reactive oxygen generation by suspensioncultured soybean cells. Plant Physiol 2000, 124(2):725-732.

40. Wang AR, Chen X, Zhang DM, Chen HH, Lu GD, Wang ZH: Effects of different Arabidopsis ROPs on multiplication of Pseudomonas syringae pv. tomato DC3000. J Fujian Agric For Univ (Natural Science Edition) 2008, 37(6):610-613.

41. Schultheiss H, Dechert C, Kogel KH, Hückelhoven R: A small GTP-binding host protein is required for entry of powdery mildew fungus into epidermal cells of barley. Plant Physiol 2002, 128(4):1447-1454.

42. Pathuri IP, Zellerhoff N, Schaffrath U, Hensel G, Kumlehn J, Kogel KH, Eichmann R, Hückelhoven R: Constitutively activated barley ROPs modulate epidermal cell size, defense reactions and interactions with fungal leaf pathogens. Plant Cell Rep 2008, 27(12):1877-1887.

43. Hoefle C, Huesmann C, Schultheiss H: A barley ROP GTPase ACTIVATING PROTEIN associates with microtubules and regulates entry of the barley powdery mildew fungus into leaf epidermal cells. Plant Cell 2011, 23 (6):2422-2439.

44. Schiene K, Puhler A, Niehaus K: Transgenic tobacco plants that express an antisense construct derived from a Medicago sativa cDNA encoding a Rac-related small GTP-binding protein fail to develop necrotic lesions upon elicitor infiltration. Mol Gen Genet 2000, 263(5):761-770.

45. Leonard MK, Hannah FB, Christine S, Wimmer D, Korte J, Schmitz U, Niehaus K, Colditz F: Silencing of the Rac1 GTPase MtROP9 in medicago truncatula stimulates early mycorrhizal and oomycete root colonizations but negatively affects rhizobial infection. Plant Physiol 2012, 159(1):501-516.

46. Doke $\mathrm{N}$ : Involvement of superoxide anion generation in the hypersensitive response of potato tuber tissues to infection with an incompatible race of Phytophthora infestans and to the hyphal wall components. Physiol Plant Pathol 1983, 23:345-357.

47. Yoshioka H, Numata N, Nakajima S, Katou S, Kawakita K, Rowland O, Jones JD, Doke N: Nicotiana benthamiana gp91phox homologs NbrbohA and NbrbohB participate in $\mathrm{H} 2 \mathrm{O} 2$ accumulation and resistance to Phytophthora infestans. Plant Cell 2003, 15(3):706-718.

48. Lamb C, Dixon RA: The oxidative burst in plant disease resistance. Annu Rev Plant Physiol Plant Mol Biol 1997, 48:251-275

49. Delledonne M, Zeier J, Marocco A, Lamb C: Signal interactions between nitric oxide and reactive oxygen intermediates in the plant hypersensitive disease resistance response. Proc Natl Acad Sci U S A 2001, 98:13454-13459.

50. Kim DS, Jeun Y, Hwang BK: The pepper patatin-like phospholipase CaPLP1 functions in plant cell death and defense signaling. Plant $\mathrm{Mol}$ Biol 2014, 84(3):329-344.

51. Ono E, Wong HL, Kawasaki T, Hasegawa M, Kodama O, Shimamoto K: Essential role of the small GTPase Rac in disease resistance of rice. Proc Natl Acad Sci U S A 2001, 98:759-764.

52. Glazebrook J: Contrasting mechanisms of defense against biotrophic and necrotrophic pathogens. Annu Rev Phytopathol 2005, 43:205-227.

53. Kunkel BN, Brooks DM: Cross talk between signaling pathways in pathogen defense. Curr Opin Plant Biol 2002, 5:325-331.

54. Durrant WE, Dong X: Systemic acquired resistance. Annu Rev Phytopathol 2004, 42:185-209.

55. Halim V, Eschen-Lippold L, Altmann S, Birschwilks M, Scheel D, Rosahl S Salicylic acid is important for basal defense of Solanum tuberosum against Phytophthora infestans. Mol Plant-Microbe Interact 2007, 11:1346-1352.

56. Coquoz JL, Buchala AJ, Meuwly P, Métraux JP: Arachidonic acid induces local but not systemic synthesis of salicylic acid and confers systemic resistance in potato plants to Phytophthora infestans and Alternaria solani. Biochem Cell Biol 1995, 85:1219-1224.

57. Penninckx IA, Thomma BP, Buchala A, Métraux JP, Broekaert WF: Concomitant activation of jamonate and ethylene response pathways is required for induction of a plant defensin gene in Arabidopsis. Plant Cell 1998, 10(12):2103-2113.

58. Spoel SH, Koornnef A, Claessens SM, Korzelius JP, Van Pelt JA, Mueller MJ, Buchala AJ, Métraux JP, Brown R, Kazan K, Van Loon LC, Dong X, Pieterse CM: NPR1 modulates cross-talk between salicylate- and jasmonatedependent defense pathways through a novel function in the cytosol. Plant Cell 2003, 15(3):760-770.

59. Truman W: Arabiodopsis systemic immunity uses conserved defence signaling pathways and is mediated by jasmonates. Proc Natl Acad Sci U S A 2007, 104(3):1075-1080.

60. Van Wees SCM, Chang H-S, Zhu T, Glazebrook J: Characterization of the early response of Arabidopsis to Alternaria brassicicola infection using expression profiling. Plant Physiol 2003, 132(2):606-617.

61. Segal AW, Abo A: The biochemical basis of the NADPH oxidase of phagocytes. Trends Biochem Sci 1993, 18:43-47.

62. Keller T, Damude HG, Werner D, Doerner P, Dixon RA, Lamb C: A plant homolog of the neutrophil NADPH oxidase gp91phox subunit gene encodes a plasma membrane protein with $\mathrm{Ca} 2+$ binding motifs. Plant Cell 1998, 10:255-266.

63. Neill S, Desikan R, Hancock J: Hydrogen peroxide signaling. Curr Opin Plant Biol 2002, 5(5):388-395

64. Letian C, Kenji S, Takashi T, Miki D, Aoyama M, Wong HL, Kawasaki T, Shimamoto K: Analysis of the Rac/Rop small GTPase family in rice: expression, subcellular localization and role in disease resistance. Plant Cell Physiol 2010, 51(4):585-595

65. Suharsono U, Fujisawa Y, Kawasaki T, Iwasaki Y, Satoh H, Shimamoto K: The heterotrimeric $\mathrm{G}$ protein a subunit acts upstream of the small GTPase Rac in disease resistance of rice. Proc Natl Acad Sci U S A 2002, 99 (20):13307-13312.

66. Wolfgang M, Keiko Y, Daniel FK: Involvement of the small GTPase Rac in the defense responses of tobacco to pathogen. MPMI 2005, 18(2):116-124.

67. Morel J, Fromentin J, Blein JP, Simon-Plas F, Elmayan T: Rac regulation of $\mathrm{NtrbohD}$, the oxidase responsible for the oxidative burst in elicited tobacco cell. Plant J 2004, 37(2):282-293.

68. Lambeth JD: Regulation of the phagocyte respiratory burst oxidase by protein interactions. J Biochem Mol Biol 2000, 33:427-439.

69. Bokoch GM, Diebold BA: Current molecular models for NADPH oxidase regulation by Rac GTPase. Blood 2002, 100:2692-2696.

70. Gao L, Tu ZJ, Millett BP, Bradeen JM: Insights into organ-specific pathogen defense responses in plants: RNA-seq analysis of potato tuber-Phytophthora infestans interactions. BMC Genomics 2013, 14:340.

71. Frank VB, Eva $V$, James FD, Dirk I: The role of active oxygen species in plant signal transduction. Plant Sci 2001, 161:405-414.

72. Na R, Zhang Z, Yu X, Zhang $X$, Yang F, Zhao J: ROS and salicylic acid (SA) play roles on the resistance establishment of the potato cultivar Zihuabai to Phytophthora infestans. J Plant Dis Prot 2013, 119(5/6):191-199 
73. Eschen-Lippold L, Altmann S, Rosahl S: DL-beta-aminobutyric acid-induced resistance of potato against Phytophthora infestans requires salicylic acid but not oxylipins. Mol Plant Microbe Interact 2010, 23(5):585-592.

74. Dong X: NPR1, all things considered. Curr Opin Plant Biol 2004, 7:547-552.

75. Divi UK, Rahman T, Krishna P: Brassinosteroid-mediated stress tolerance in Arabidopsis shows interactions with abscisic acid, ethylene and salicylic acid pathways. BMC Plant Biol 2010, 10:151.

76. Choi J, Huh SU, Kojima M, Sakakibara H, Paek KH, Hwang I: The cytokininactivated transcription factor ARR2 promotes plant immunity via TGA3/ NPR1-dependent salicylic acid signaling in Arabidopsis. Dev Cell 2010, 19:284-295.

77. Navarro L, Bari R, Achard P, Lisón P, Nemri A, Harberd NP, Jones JD: DELLAs control plant immune responses by modulating the balance of jasmonic acid and salicylic acid signaling. Curr Biol 2008, 18(9):650-655.

78. Hu C: Screening of Potato Clones with Horizontal Resistance to Late Blight (Phytophthora Infestans). Wu Ha: Huazhong Agricultural University; 2003.

79. Hernández JA, Ferrer MA, Jiménez A, Barceló AR, Sevilla F: Antioxidant systems and $02 .-/ \mathrm{H} 2 \mathrm{O} 2$ production in the apoplast of pea leaves. Its relation with salt-induced necrotic lesions in minor veins. Plant Physiol 2001, 127(3):817-831.

80. Su GX, An ZF, Liu YL, Liu Y: Light promotes the synthesis of lignin through the production of $\mathrm{H} 2 \mathrm{O} 2$ mediated by diamine oxidases in soybean hypocotyls. J Plant Phys 2005, 162(2):1297-1303.

81. Wang Z, Mao H, Dong C, Ji R, Cai L, Fu H, Liu S: Overexpression of Brassica napus MPK4 enhance resistance to sclerotinia sclerotiorum in oilseed rape. MPMI 2009, 22(3):235-244.

82. Doyle JJ, Doyle JL: A rapid DNA isolation procedure for small quantities of leaf tissue. Phytochem Bull 1987, 19:11-15.

83. Lennart EL, Grit R, Michael S, Göbel C, Feussner I, Rosahl S: Reduction of divinyl ether-containing polyunsaturated fatty acids in transgenic potato plants. Phytochemistry 2007, 68:797-801.

\section{Submit your next manuscript to BioMed Central and take full advantage of:}

- Convenient online submission

- Thorough peer review

- No space constraints or color figure charges

- Immediate publication on acceptance

- Inclusion in PubMed, CAS, Scopus and Google Scholar

- Research which is freely available for redistribution

Submit your manuscript at www.biomedcentral.com/submit

C) Biomed Central 